\title{
Books
}

Ireland's civil engineering heritage

by Ronald Cox and Philip Donald, published by The Collins Press, 2013 f17.99, reviewed by John Clifton, Portugal

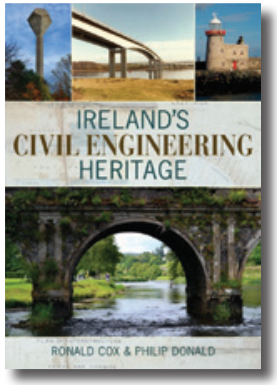

This textbook-sized glossy is actually two books in one: an historical review of the various infrastructure sectors - roads, canals, railways, water and drainage and maritime - followed by a geographical gazetteer of surviving works, from the grandiose Foyle Bridge to the blunt University College Dublin water tower.

The historical review is the highlight, with a span of over a millennium and a cast of many unexpected and lesserknown 'engineers', from seventh century Nendrum monks and their tide-mill to the energetic and splendidly named Binden Blood Stone. There are cameo appearances by some engineering great and good - such as Robert Stevenson, both John Rennies and Brunel although celebrities did not always get it right in designing for Irish ground conditions.

There is a hint of folklore in some of the accounts and the reader is left wanting to know more. Why, for example, were the final locks on the Ulster canal built too narrow for the barges to pass through, and why was the Ballinamore and Ballyconnell Navigation only used by eight vessels in 9 years?

There are also some eighteenth century aphorisms relevant to justifying modern infrastructure, such as, 'have something to carry before you seek the means of carriage' and the conclusion that much Irish infrastructure could be justified only as a means of employment generation.

Modern politicians contemplating public works programmes in these straitened economic times should take note. Highly recommended.

\section{Bridge design and} evaluation - LRFD and LRFR

by Gongkang

Fu, published by Wiley, 2013, f85, reviewed by lain Gibb, Independent Consultant, UK

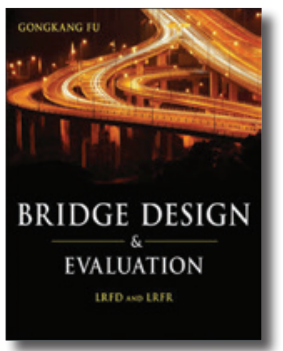

If Aashto is your main reference code for beam-and-slab bridge design then this book will be very useful, as it covers both the load and resistance factor design (LRFD) and the load and resistance factor rating (LRFR) methods.

Almost half of the 420 pages are devoted to the design of bridge decks, with well-explained, fully worked examples for medium-span decks. The calculations and diagrams are clear, enabling good comparisons between use of rolled steel beams, plate girders and prestressed concrete beams to support the top slab.

The reader is then taken through the parallel process of evaluating bridge components to illustrate the code differences between design and evaluation. Shear connection and fatigue analysis are covered but bracing and diaphragm components are not, other than by reference to their roles.

The book also covers bearings and non-piled substructures. The comprehensive illustrations and photographs give good insight into bridge components, and flow charts aid understanding of each analysis process. There is a short section to illustrate longspan forms of bridges - cable stayed, suspension, truss and arch - to give the reader an insight on more complex structures.

Overall, therefore, if you work with the Aashto codes (and are used to US imperial units) this will be a very useful textbook.
Reliability of

structures (2nd edition)

by Andrzej Nowak and Kevin Collins, published by CRC Press, 2012, f63.99, reviewed by Jimmy Kim, University of Colorado Denver, USA



This second edition of Novak and Collins' book comprises ten chapters covering a variety of technical content, such as the basics of probability, simulation techniques, modelling structural loads, safety analysis and some design issues.

The widely used Monte Carlo simulation is elaborated in chapter 4 . The examples of how to generate statistical data for normal and lognormal random numbers are likely to be helpful for practising engineers and students interested in statistical modelling.

The background of limit-state design is provided in chapter 5 in conjunction with detailed explanations on reliability index. The first-order second-moment reliability method is covered with a typical structural problem, and a stepby-step procedure is summarised to implement the Hasofer-Lind reliability index, supported by several examples.

Chapter 6 reveals various load models for structural design. Bias factors and coefficient of variation are specified for dead and live loads. The live load models used in the Aashto specifications are illustrated with some parametric study results. Other types of loads such as wind, snow, ice and earthquake are concisely discussed.

The last chapter of the book is about uncertainties in the building process. Of interest are human error, uncertainty categories and failure rates. Overall, this book is informative and practical and I recommend it as a reference for practising engineers, engineering students and research professionals. 
The ICE library carries one of the most comprehensive ranges of civil engineering books in the world, including all titles from ICE Publishing (shown in bold below). New books received in the past 3 months include the following.

\begin{tabular}{|c|c|c|}
\hline A better way to build: a history of the Pankow companies & M Adamson & $\mathrm{f} 31 \cdot 16$ \\
\hline BIM for facility managers & P Teicholz & $f 57 \cdot 50$ \\
\hline Biomass as energy source: resources, systems and applications & E Dahlquist & $f 82 \cdot 00$ \\
\hline Bridge construction equipment & M Rosignoli & $f 80.00$ \\
\hline Building services handbook (7th edition) & R Greeno & f29.99 \\
\hline CESMM4 carbon and price book 2013 (8th edition) & Mott MacDonald & $f 160 \cdot 00$ \\
\hline $\begin{array}{l}\text { Concrete, from archeology to invention, 1700-1769: the renaissance of Pozzolana and Roman } \\
\text { construction techniques }\end{array}$ & R Gargiani & f65.00 \\
\hline Construction law: law and practice relating to the construction industry (11th edition) & J Uff & f30.95 \\
\hline Corrosion of steel in concrete: prevention, diagnosis, repair (2nd edition) & L Bertolini & $f 86 \cdot 40$ \\
\hline Critical excitation methods in earthquake engineering ( 2 nd edition) & I Takewaki & $f 100 \cdot 00$ \\
\hline Design against blast: load definition and structural response & S Syngellakis & f93.00 \\
\hline Design and construction of nuclear power plants & J Schnell & $f 45 \cdot 00$ \\
\hline Design of fastenings for use in concrete - the CEN/TS 1992-4 provisions & R Mallee & $f 45 \cdot 00$ \\
\hline Design of structural elements to Eurocodes (2nd edition) & W McKenzie & f38.99 \\
\hline Environmental geotechnics (2nd edition) & R Sarsby & $\mathbf{f 1 0 0 \cdot 0 0}$ \\
\hline Environmental impacts of hydraulic fracturing & F Spellman & $f 82 \cdot 00$ \\
\hline FRP deck and steel girder bridge systems: analysis and design & J Davalos & f95.00 \\
\hline Green buildings pay: design, productivity and ecology (3rd edition) & B Edwards & f35.00 \\
\hline How to plan and implement seismic isolation for buildings & Japan Society of Seismic Isolation & f98.68 \\
\hline Intelligent buildings: design, management and operation (2nd edition) & D Clements-Croome & $\mathbf{f 4 5 . 0 0}$ \\
\hline Leak detection: technology and implementation & S Hamilton & f75.00 \\
\hline Low carbon development: key issues & F Urban & f26.99 \\
\hline Management of global construction projects & E Ochieng & f34.99 \\
\hline Managing climate risk in water supply systems & C Brown & f79.00 \\
\hline Manual for the geotechnical design of structures to Eurocode 7 & The Institution of Structural Engineers & f70.00 \\
\hline Milestones in water reuse: the best success stories & V Lazarova & f99.00 \\
\hline Natural ventilation in high-rise office buildings & A Wood & f39.99 \\
\hline One Great George Street: the headquarters building of the Institution of Civil Engineers & M Dunkeld & $f 45 \cdot 00$ \\
\hline Safer stairs in public places - assessment of existing stairs & A Gilbertson & $f 50 \cdot 00$ \\
\hline Seismic behaviour and design of irregular and complex civil structures & O Lavan & $f 117 \cdot 00$ \\
\hline Statics and mechanics of structures & S Krenk & f53.99 \\
\hline Steel-concrete composite bridges: designing with Eurocodes (2nd edition) & D Collings & $\mathbf{f 7 5 . 0 0}$ \\
\hline Steel bridges: conceptual and structural design of steel and steel-concrete composite bridges & J Lebet & $\mathrm{f} 72.68$ \\
\hline $\begin{array}{l}\text { Technologies for converting biomass to useful energy: combustion, gasification, pyrolysis, } \\
\text { torrefaction and fermentation }\end{array}$ & E Dahlquist & $\mathrm{f} 82 \cdot 00$ \\
\hline The deep mixing method & M Kitazume & 689.00 \\
\hline The design manager's handbook & J Eynon & f39.95 \\
\hline The governance of energy megaprojects: politics, hubris and energy security & B Sovacool & 680.00 \\
\hline The Intercity story 1964-2012 & C Green & f35.00 \\
\hline Total sustainability in the built environment & A Cotgrave & f36.99 \\
\hline Towers, turbines and transmission lines: impacts on property value & S Bond & f65.00 \\
\hline Underground engineering for sustainable urban development & National Research Council & f40.00 \\
\hline Understanding building failures (4th edition) & J Douglas & £29.99 \\
\hline Urban energy systems: an integrated approach & J Keirstead & f35.00 \\
\hline Water and wastewater infrastructure: energy efficiency and sustainability & F Spellman & f70.16 \\
\hline Worked examples for the design of concrete structures to Eurocode 2 & T Threlfall & $f 35.00$ \\
\hline
\end{tabular}

